\title{
EUROPEAN EXPERIENCE IN TEACHER EDUCATION AND PEDAGOGICAL MASTERY DEVELOPMENT
}

\begin{abstract}
In the article the author considers recent trends in teacher education and pedagogical mastery, issues of carrying out improvements to the teacher training system in European countries, analyzes programmes of cooperation in education that facilitate forming of teachers' professional competency, studies typical problems in teacher education in Europe and possible ways for its improving. Based on the study of European experience in teacher training the author has concluded that lecturers are extremely interested in identifying the patterns of teacher training and pedagogical mastery as a theoretical, methodological and practical problem and has justified the importance of the structural organization and modernization of teacher professional training in higher education, the development of new forms in relations between the teacher training system and higher education institutions, which are based on systematic, scientific, interdisciplinary approaches and the idea of continuity. The importance of special cooperation projects in teacher education launched in the European Union in terms of pedagogical mastery has been emphasized in the article. The author also focuses attention on new ways of solving the existing problems in developing the professional competency of students obtaining teacher education as well as the development of pedagogical mastery. There have been described main directions in the functioning of European countries' teacher training systems that can be useful in identifying development trends in teacher education in Ukraine, namely, teacher education based on worldwide recognized researches, the shift in orientation of the teacher education philosophy: from quantity to quality, clearly defined educational standards as well as criteria for their assessment, the review of procedures for accrediting teacher training institutions, the use of multimedia technologies.
\end{abstract}

Key words: teacher education, pedagogical mastery, education institutions, curriculum, the Bologna process, cooperation programmes in education, practical training, mentor.

\section{INTRODUCTION}

Nowadays when the problem of modern professional teacher training is of great importance in pedagogy, the analysis of foreign experience, European, in particular, in teacher training, tendencies and prospects of pedagogical mastery, international cooperation among scientists in carrying out researches on this process is rather interesting as a theoretical, methodological and practical problem. Revealing of the patterns and tendencies in this process can become a source of the utmost importance in identifying trends in teacher education development in Ukraine.

Presently teacher education in European countries is undergoing considerable changes; all the structures of the national teacher education systems are being renewed; the content and methods of teacher training are being modernized; new forms of relations between the teacher training system and higher education are being developed. 
Over the 1990s we witnessed the emergence of new concepts and the term "European dimension of education" that resulted from development of common training space in Europe. Every country is currently putting into practice its own strategy for renewing its teacher training system.

In the context of Ukraine's integration into the European Community the relations and interaction with other countries in teacher training are being strengthened. Thus, the question of studying and implementing European countries' experience in teacher training is rather topical in Ukraine.

\section{THE AIM OF THE STUDY}

The aim of the study is to consider and analyze the functioning of higher teacher education in Europe. In accordance with the aim the following tasks were set: to examine the current teacher training trends in European countries, identify and analyze the main functions of higher teacher education in the countries the experience of which has been studied.

\section{THEORETICAL FRAMEWORK AND RESEARCH METHODS}

The theory and practice of the educational process abroad have been studied by such leading Ukrainian scientists such V. Chervonetskyi, O. Matviyenko, L. Pukhovska, I. Ziaziun. However, there still remain a number of insufficiently studied teacher training issues related to changes in the European teacher education system. The use of experience gained by pedagogical universities in the European Union will contribute to deeper understanding of problems in Ukrainian teacher education as well as foreseeing and optimizing activities of national teacher training system.

The methodological framework of the study consists of cognitive theory foundations, general scientific approaches and principles, namely, systematic, paradigmatical, functional, comparative approaches, the principles of scientific content, objectivity, interactivity as well as concrete scientific principles of historism, combination of the logical and the historical, ideas of education globalization.

The realization of the aim required the use of such research methods as structural, interpretative and analytical, prognostic.

\section{RESULTS}

Up to the last decade of the XX century the development of pedagogical education and pedagogical mastery in European countries were not directly connected with issues of European or international cooperation in education. At the beginning of the 1990s national systems of education in European countries took on additional challenges. Internal internationalization (the process of Europeanisation) affected different aspects. The major determinants of politics that became known at the end of the 1980s were: 1) an agreement made by 12 European countries ensuring that the European Community is responsible for coordinating education policy; 2) significant changes in policies of Central and Eastern European countries that resulted from the fall of the Berlin Wall (Zgaga, 2011).

During past decades education was not the first priority in the course of gradual uniting European countries. Nowadays professional education attracts more attention in the European Union countries because vocational qualifications are of great importance to economic cooperation.

At the practical level direct cooperation among education institutions in the European Union countries considerably increased in the late 1980s. In 1990s the enlargement of the European Union started. It was a matter of great importance to pedagogical mastery that particular cooperation projects were initiated in the European Union which contributed to further cooperation in education. For instance, a lot of opportunities for strengthening 
cooperation among teacher education institutions from more than 50 European as well as non-European countries have been offered by the Tempus programme.

The Association for Teacher Education in Europe (ATEE) is a widely-known nongovernmental organization consisting of 60 representatives from more than 40 countries that concentrates its efforts on the teachers' pedagogical mastery. At the beginning of the 1990s ATEE prepared a comparative analysis of teacher training curricula in the countries of European Union. It was rather essential during the first years of strengthening collaboration in the field of teacher education and still is.

In 1994 the European Trade Unions Committee for Education (ETUCE) released the document on "Teacher Education in Europe" dealing with the following: the organization, content of teacher education, equal opportunities and intercultural education, the European dimension and mobility, teachers' professionalism.

In Europe teacher education is the most regulated sector of higher education system. That explains why the public focus their attention on teacher education. Recommendations and minimum requirements were set either by departments of education or higher education institutions. Occasionally, the level of regulation is considered to be rather strict. For instance, the Department of Education in the Netherlands make decisions on the framework of qualifications as well as on the teachers' knowledge base. Moreover, they plan national examinations for teachers (Požarnik, 2011).

According to the requirements introduced by the Bologna process the curricula of teacher education were renewed in all countries. The first priority was to decide on the level of necessary education for different types of teachers; the study cycle they should be trained at. Such countries as Croatia, the Czech Republic, Finland, Slovenia decided that all teachers should receive education at the second cycle after five years of studies (so called "masterization" in teacher education). Sweden, Norway, the Netherlands adopted a different, more flexible system of teacher training that is based on two models: the model of parallel training that implies studying academic disciplines and disciplines of psychological and pedagogical cycle simultaneously throughout the course which leads to the Bachelor of Education; the model of consecutive training where specialized teacher training should be given after the qualification of specific field has been obtained (Musset, 2010).

For some countries the transition to the Bologna system became the challenge and, thus, resulted in fundamental structural changes. Finland, which had already offered a Master degree for all future teachers, considered the Bologna process to be a stage of national analysis and assessment of teacher education curricula rather than a fundamental change (Požarnik, 2011).

Nowadays in most countries pedagogical institutions belong to universities. The attitude to such a process of teacher education universitization in Europe is ambiguous. Usual but not common to all universities is the pattern that teacher education faculties should deal with training specialists for primary education; others (of humanities, arts, sciences) offer academic training for other professions as well as educate teachers for secondary school.

The Bologna process has resulted in a better defined and more unified professional component of teacher education consisting of one year studies and including, in addition to traditional components (didactics, psychology, methods of subject teaching), elements of such sciences as sociology, philosophy of education. In some countries, such as Finland, Slovenia, they also include the research methodology giving particular attention to qualitative research to make it possible for teachers to grow as researchers in their profession. In most 
cases that means a greater degree of balance kept between academic and professional components of curricula. Professionalisation of teacher education is a slow process at traditional higher education institutions because it requires changes in understanding objectives.

Strengthening practical training based at school both quantitatively and qualitatively is another feature renewed curricula have in common. The practice lasts from 5 to 15 weeks. Some countries have a long tradition of introducing students to the teaching career intensively right from the start of studies, other ones are still in the process of its developing. Different stages provide different focus for a practical component. In the Czech Republic, for instance, they have initial, subject, observational, research practice. In Slovenia and the Netherlands practice consists in active observation, supervised conduct of classes and independent teaching. The last phase of the studies requires that students should spend half a year on work experience in teaching. Both university lecturers and lecturers from the educational institutions collaborating with that university are to supervise work experience. During the assessment of work experience the portfolio is given more attention. Partnership of faculties with other educational institutions is supported by the European Union corresponding programmes. Some states have established specific training schools (Požarnik, 2011).

There are countries that do not require a probation period, and a teacher obtains full qualification or becomes licensed upon graduation from university (Ukraine, the Netherlands, Russia). In the Netherlands, probably, there is the largest amount of independent practice in education institutions that makes such special induction period unnecessary. In most countries the teachers that have just obtained qualification are to spend the first year or two as probationers teaching part-time and earning somewhat a lower salary under his mentor's close supervision. At the end of this period they are to pass a state exam which gives them right to be fully licensed teachers.

Universities are usually not involved in this process. Mentors are allowed to conduct fewer classes as compensation for assisting probationers. Estonia can serve as an example of systematic support to newly qualified teachers in their professional growth. They introduced the induction year programme for all teachers in 2004-2005. According to this programme they are to attend courses organized by university centres of induction year who also train mentors to support newly-qualified teachers in their professional development. The assessment study conducted on the programme of induction identified the following aspects that require improving: increasing novices' readiness for teaching; training mentors to perform their functions; increasing head teachers' willingness to help newly-qualified teachers in their professional growth. Such countries as Sweden, Slovenia, the Netherlands also offer the training for mentors. It is not compulsory, though (Požarnik, 2011).

The state examinations finalizing a probation period differ greatly in terms of range and content. There are countries where this procedure comprises oral and written exams in didactics like those taken for a second diploma and is characterized by severe requirements (Romania). In some countries the candidates for a position of a teacher are to prove their abilities by conducting model classes in front of committee members (Croatia). Candidates in Slovenia provide documents on the classes observed and assessed as positive by mentors and the representative of the education institution administration and take examinations on the law systems in Slovenia as well as the European Union, the educational laws, Slovene.

Most countries offer postgraduate courses which can be doctoral, those qualifying graduates to work as teachers of one more subject, perform specific duties (such as counseling, teaching the students with special needs) (Požarnik, 2011). 
Nowadays scientists who research into issues of teacher education and pedagogical mastery in European countries identify the following typical problems solving which is a high priority because they are closely connected with the professional competency of teachers:

- the motivation level and cognitive capabilities of applicants for teacher education are decreasing;

- teachers' social status as well as self-esteem are low;

- insufficient number of qualified teachers of particular disciplines;

- the employment of unqualified teachers;

- researches on teacher education and systematic monitoring are insufficient;

- research results on teaching and learning disciplines are not implemented into practice;

- teachers are unable to carry out the analysis of the effectiveness of their work, to team up and cooperate as they are unmotivated;

- theory and practice as well as academic and professional components of education are insufficiently balanced;

- teachers suffer from occupational burn-out;

- they are unable to manage difficulties caused by the behavior of students;

- the level of professional autonomy is low;

- there is no clear policy in teacher education (Požarnik, 2011).

In order to solve the problem of forming professional competency of future teachers and pedagogical mastery Slovenian scientists give the following recommendations:

- teacher education should be based on internationally recognized researches;

- the philosophy of teacher education should be radically changed from quantityto quality-oriented; formulated;

- professional standards as well as criteria for their assessing should be clearly be revised;

- accreditation procedures for teacher education institutions and curricula should

- resources should be sufficiently allocated;

- the flow of information on didactic resources, the use of multimedia technologies should be improved (Požarnik, 2011).

Estonian researchers also make a suggestion that more attention should be focused on relations and cooperation among participants in education, namely, state, higher education institutions responsible for education, the very teachers and their associations.

CONCLUSIONS

The training of future teachers performed in teacher education institutions and pedagogical mastery are integral components of higher education system in European countries. Higher pedagogical education in Europe is directed at:

- giving a future teacher necessary knowledge of psychological and pedagogical cycle and transforming it into practical skills;

- identifying problems and disadvantages and analyzing reasons for their appearance;

- taking certain measures to prevent and remove them;

- carrying out research and practical training at an education institution;

- planning the process of teaching;

- organizing students' independent learning; into practice.

- creating conditions for implementing scientific findings in psychology and pedagogy 
The results of the effective organization of the educational process at teacher education institutions in the countries whose experience has been studied are knowledge, practical skills, personal attributes necessary for the professional activity that are acquired by future teachers.

In our opinion, it is necessary and useful to conduct further research into teacher education and pedagogical mastery in European educational institutions. Further study of effectiveness of professional teacher training and pedagogical mastery at universities in European countries as well as studies of possibilities for implementing the results of the research in the Ukrainian higher education system we consider rather perspective. Making use of the experience that has been gained by specialists from the European Union will facilitate optimization of the Ukrainian system of teacher training and pedagogical mastery.

\section{REFERENCES}

1. ETUCE. (1994). Teacher Education in Europe. Retrieved 4.082014 from : http://see-educoop.net/portal/id misc.htm.

2. Miller, S., Taylor, $\overline{\mathrm{Ph}}$. (1993). The Teacher Education Curricula in the Member States of the European Community. ATEE Cahiers.

3. Musset, P. (2010). Initial Teacher Education and Continuing Training Policies in a Comparative Perspective: Current Practices in OESD Countries and a Literature Review on Potential Effects. Retrieved 4.08.2014 from : http://dx.doi.org/10,1787/ $5 \mathrm{kmbphh} 7 \mathrm{~s} 47 \mathrm{~h}-\mathrm{en}$.

4. Požarnik, B. (2011). Teacher Education in Europe between Unity and Diversity. In: Zulian, M. V. \& Vogrinc, J. (Eds.). European Dimensions of Teacher Education: Similarities and Differences. Ljubljana : Faculty of Education, pp. 22-31.

5. Zgaga, P. (2011). Why We Need to Learn One from Another and Work Together? In: Zulian, M. V. \& Vogrinc, J. (Eds.). European Dimensions of Teacher Education: Similarities and Differences. Ljubljana : Faculty of Education, pp. 11-21. 